\title{
PHYTOCHEMICAL SCREENING AND ANTIBACTERIAL ACTIVITY OF TWO DIFFERENT SPECIES OF CRUSTOSE LICHEN FROM KALYANI UNIVERSITY CAMPUS, WEST BENGAL, INDIA
}

\author{
S. Majumder ${ }^{1} \bowtie$, S.N. Sinha ${ }^{1}$ \\ ${ }^{1}$ Environmental Microbiology Research Laboratory, Department of Botany, University of Kalyani, West \\ Bengal, India.
}

\section{ABSTRACT}

Lichens are universally distributed organism occurring in varied climatic condition ranging from the poles to the tropics in earth. The study of lichen remains quite frowzy throughout the world. Though the importance of lichen in an ecosystem is very high in its own way. Lichens are just like miniature sponges that take up everything that comes their path, including air pollution Fleishner TL. (1994). They synthesise many useful secondary metabolites. Among the synthesised metabolites, many of them have antiviral and antibacterial activity. To keep this view in mind the present study has done to to evaluate the antibacterial activity of two different crustose lichen species collected from Kalyani University Campus, WB. Since this is the first time study of antimicrobial activity of Cryptothecia striata and Cryptothecia scripta.

Keywords: Crustose Lichen, Antimicrobial Activity, Phytochemicals, Kalyani University

\section{INTRODUTION}

Received 20 July 2021

Accepted 05 August2021

Published 18 August 2021

\section{CorrespondingAuthor}

S. Majumder, smajumder959@gmail.com

\section{DOI 10.29121/ijetmr.v8.i8.2021.1011}

Funding: This research received no specific grant from any funding agency in the public, commercial, or not-for-profit sectors.

Copyright: (C) 2021 The Author(s). This is an open access article distributed under the terms of the Creative Commons Attribution License, which permits unrestricted use, distribution, and reproduction in any medium, provided the original author and source are credited.
Lichen is a unique group of plant that consist of two unrelated organisms a fungus and an algae, growing together in a close symbiotic association. They may appear like crust and spreading rapidly over the surface (Crustose lichen) or leaf like and loosely attached to the surface (Foliose lichens) or shrubby and branched, dangling from the tree twing or branches, with a single attachment (Fruticose lichens). Lichens are originally interpreted as single organism and treated as their own systematic category, Lichens, separate from fungi, mosses and algae (Honegger 2009). The distinctive colours of many lichens result from the massive accumulation of diverse secondary compounds the so called "Lichen substances" which can comprise up to $29 \%$ of a lichen's dry weight. This secondary compounds are mainly small, structurally complex molecules Huneck S and Yoshimura I. (1996). Most of the lichen substances are phenolic compounds, anthraquinones, diberzofurans, pulvinic acid (Stubler \& Buchenauer 1996). In the present study, an attempt has been made to evaluate the antibacterial activity of two different crustose lichen species collected from Kalyani University Campus, WB. 


\section{MATERIALS AND METHODS}

\subsection{STUDY AREA}

The study was conducted at Kalyani University Campus which is situated in the district of Nadia, West Bengal (Latitude 2304/N, Longitude 88052/E). This University campus has 400 acre field area and different types of plants.

\subsection{SAMPLING}

The study was carried out during the period of March 2020. During which the average maximum and minimum temperature was $36^{\circ} \mathrm{C}$ and $14^{\circ} \mathrm{C}$ and the average value of relative humidity was $86 \%$.

The lichen sample collected from trees upto a height of about $10 \mathrm{ft}$. Specimens were collected in paper bags and brought to the laboratory for analyses. Specimens are presented in the herbarium of Department of Botany, University of Kalyani, Kalyani, Nadia, WB.

\subsection{IDENTIFICATION}

The lichen specimens were collected from all the available substrates (i.e. Tree bark, Twing, Leaf surface, Rock, Forest flore etc.) The collected specimens after their proper drying, were investigated morphologically, anatomically and chemically (Upreti DK, Divakar PK, Nayaka S (2005)). The color spot tests were performed with the usual reagents of $\mathrm{K}(5 \%$ Potassium hydroxide), C (Aqueous soln. of Calcium hypochlorite) and P (Paraphenylenediamine)( Rashmi S and Rajkumar HG. (2014) ).

\subsection{PHYTOCHEMICAL SCREENING}

\subsubsection{QUALITATIVE CHEMICAL EVALUATION}

The obtained different lichen extracts were qualitatively examined for the presence of various phytochemicals.

\subsubsection{TEST FOR TANNINS}

Ferric chloride Test; 2 ml Crude extract was mixed with a few drops of $5 \%$ ferric chloride solution. Formation of a blue colour showed the presence of tannins.

\subsubsection{TEST FOR ALKALOIDS}

Dragondroff's test; $2 \mathrm{ml}$ of crude extract is added to $1 \% \mathrm{HCl}$, steam for 10 minutes. To this add 5 drops Dragondroff's reagent; the reddish

- brown precipitate indicates the presence of alkaloids.

\subsubsection{TEST FOR SAPONINS}

$2 \mathrm{ml}$ of Crude lichen extract was mixed with $5 \mathrm{ml}$ of distilled $\mathrm{H}_{2} \mathrm{O}$ in a test tube and it was shaken vigorously. The formation of a foam shows the presence of saponins.

\subsubsection{TEST FOR GLYCOSIDES}

Keller-kilani test: $2 \mathrm{ml}$ of lichen Crude extract was added with $2 \mathrm{ml}$ of glacial acetic acid and 1-2 drops of $2 \%$ solution of $\mathrm{FeCl}_{3}$. The mixture was then poured into an another test tube and added $2 \mathrm{ml}$ of concentrated $\mathrm{H}_{2} \mathrm{SO}_{4}$. A brown coloured ring at the interphase showed the presence of cardiac glycosides. 


\subsubsection{TEST FOR FLAVONOIDS}

$\mathrm{NaOH}$ solution test; $2 \mathrm{ml}$ of crude extract is added to $2 \mathrm{ml}$ of $10 \% \mathrm{NaOH}$ solution. Formation of Yellowish orange colour indicates the presence of flavanoids.

\subsubsection{TEST FOR PROTEINS}

Xanthoproteic test: $2 \mathrm{ml}$ of crude lichen extract is mixed with $2 \mathrm{ml}$ of HNO3 and then boiled in a water bath. Formation of Orange colour indicates the presence of proteins.

\subsubsection{TEST FOR TRITERPENOIDS}

Salkowski Test: $2 \mathrm{ml}$ of crude lichen extract is shaken with $1 \mathrm{ml}$ of chloroform and 5 drops of concentrated sulphuric acid were added along the side of test tube. A reddish-brown colour formed at the interface showed the test as a positive for triterpenoids.

\subsubsection{TEST FOR CARBOHYDRATES}

Benedict's test: $2 \mathrm{ml}$ of Crude lichen extract when mixed with $2 \mathrm{ml}$ of Benedict's reagent and then boiled, a reddish-brown precipitate formed which showed the presence of the carbohydrates

\subsubsection{TEST FOR STEROIDS}

Liebermann-Burchard reaction: $2 \mathrm{ml}$ of crude lichen extract is added with $2 \mathrm{ml}$ acetic anhydride and a few drops of conc. $\mathrm{H}_{2} \mathrm{SO}_{4}$. Blueish green coloured ring indicates the presence of steroids.

\section{PREPARATION OF LICHEN EXTRACT}

Before extraction the plant materials were washed in tap water and then blot and dried at room temperature $\left(30+/-2^{\circ} \mathrm{C}\right)$. Then the dried material were powdered in grinder, to prepare stalk solution $10 \mathrm{gm}$ of the powder were taken and then added to $100 \mathrm{ml}$ of solvents of methanol, ethanol and distil water $(\mathrm{W} / \mathrm{V}, 10 \mathrm{gm} / 100 \mathrm{ml})$ each extract was filtrated through whatman filter paper.

\subsection{TEST ORGANISM}

Bacteria such as Micrococcus luteus; Shigella dysenteriae; Shigella flexneri; Escherichia coli; Staphylococcus aureus; Pseudomonas aeruginosa; Bacillus subtilis; Vibrio cholerae were used as test organism. All the bacterial culture were produce from ID \& BG, Hospitals, Kolkata. These bacterial strains culture maintained on nutrient plate at $4^{\circ} \mathrm{C}$ temp.

\subsection{SCREENING OF ANTIBACTERIAL}

Antibacterial test of selected microorganisms were carried out using agar well diffusion method (Perez et al. 1990). The plates were incubated at $37^{\circ} \mathrm{C}$ for 24 hours during which activity also evidence by the presence of a zone of inhibition surrounding the well. Each test was repeated three times and the antibacterial activity was expressed as the mean of diameter of the inhibition zone (mm).

\section{RESULTS AND DISCUSSION}

In the presence study two lichen sample (LK1, Cryptothecia striata and LK2, Cryptothecia scripta) were tested for the presence of different phytochemicals. The result was presented in Table 1. Both the lichens samples exhibited in the presence of saponin, tannin, terpenoids, reducing sugar and alkaloids. Flavonoids are absence 
in both the lichens. However, the lichens LK2 contained carbohydrate. These biochemical test might be utilise for the farther identification of lichens.

\begin{tabular}{cccc} 
Table1: Biochemical analysis of lichen specimens. & & \\
\hline No & Phytochemicals & LK1 & LK2 \\
1 & Tannins & + & + \\
\hline 2 & Alkaloids & + & + \\
\hline 3 & Saponins & + & + \\
\hline 4 & glycosides & - & - \\
\hline 5 & Flavonoids & - & + \\
\hline 6 & Proteins & + & + \\
7 & Triterpenoids & + & + \\
\hline 8 & Carbohydrates & - & - \\
\hline
\end{tabular}

+: Present; -: Absent; LK1: Cryptothecia striata; LK2: Cryptothecia scripta

The aqueous as well as methanolic and ethanolic extract for both lichens thallus studied for their antibacterial and it was presented in Table 2 and Table3. All the extract showed antibacterial activities against all the bacterial tests. The solvent extract shows maximum activity as compare to the water extract indicating the released of bioactive component of lichens in the solvent in greater amount. The methanolic extract of LK1 showed highest antibacterial activities and those of ethanolic extract. Methanolic extract of LK1 exhibited maximum activity against Micrococcus luteus and minimum activity against Staphylococcus aureus. On the other hand the ethanolic extract of LK1 showed maximum inhibition zone against Bacillus subtilis and minimal inhibition zone against Pseudomonas aeruginosa . On the other hand water extract of LK1 exhibited higher activity against Pseudomonas aeruginosa and less activity against $\boldsymbol{E}$. Coli.

The methanolic extract of LK2 also exhibited considerable activities against all the bacteria with highest activities recorded against $\boldsymbol{E}$. Coli and less activity against Pseudomonas aeruginosa. On the other hand the ethanolic extract of LK2 showed maximum inhibition zone against Shigella flexneri and minimal inhibition zone against Bacillus subtilis. On the other hand water extract of LK2 exhibited higher activity against Micrococcus luteus and less activity against Shigella flexneri.

\begin{tabular}{|c|c|c|c|c|c|c|c|c|}
\hline \multirow{2}{*}{$\begin{array}{l}\text { Test } \\
\text { Sample }\end{array}$} & \multicolumn{8}{|c|}{ Diameter of inhibition zone (mm) } \\
\hline & ML & SD & SF & EC & SA & PA & BS & VC \\
\hline $\begin{array}{l}\text { Methanolic } \\
\text { extract }\end{array}$ & 20 & 18.5 & 18.3 & 17.3 & 16.5 & 17 & 17.5 & 17.6 \\
\hline $\begin{array}{l}\text { Ethanolic } \\
\text { Extract }\end{array}$ & 15.6 & 16 & 15.6 & 16 & 16 & 14.3 & 16.6 & 16.3 \\
\hline $\begin{array}{l}\text { Water } \\
\text { extract }\end{array}$ & 13 & 15 & 14.5 & 12 & 14 & 16 & 14 & 12 \\
\hline
\end{tabular}

N.B: $\mathrm{ML}=$ Micrococcus luteus; $\mathrm{SD}=$ Shigella dysenteriae; $\mathrm{SF}=$ Shigella flexneri; $\mathrm{EC}=$ Escherichia coli; $\mathrm{SA}=$ Staphylococcus aureus; $\mathrm{PA}=$ Pseudomonas aeruginosa; $\mathrm{BS}=$ Bacillus subtilis; $\mathrm{VC}=$ Vibrio cholerae. 


\begin{tabular}{|c|c|c|c|c|c|c|c|c|}
\hline \multirow[t]{2}{*}{ Test Sample } & \multicolumn{8}{|c|}{ Diameter of inhibition zone (mm) } \\
\hline & ML & SD & SF & EC & SA & PA & BS & VC \\
\hline $\begin{array}{l}\text { Methanolic } \\
\text { extract }\end{array}$ & 20.5 & 21.5 & 20 & 23 & 22 & 18.6 & 22 & 19 \\
\hline $\begin{array}{l}\text { Ethanolic } \\
\text { Extract }\end{array}$ & 16 & 18.3 & 19 & 16.6 & 17 & 16 & 15 & 18.3 \\
\hline Water extract & 15 & 13.5 & 12 & 13 & 14 & 13.5 & 12.5 & 13.5 \\
\hline
\end{tabular}

N.B: $M L=$ Micrococcus luteus; $\mathrm{SD}=$ Shigella dysenteriae; $\mathrm{SF}=$ Shigella flexneri; $\mathrm{EC}=$ Escherichia coli; $\mathrm{SA}=$ Staphylococcus aureus; $\mathrm{PA}=$ Pseudomonas aeruginosa; $\mathrm{BS}=$ Bacillus subtilis; $\mathrm{VC}=$ Vibrio cholerae.

In the present study both gram positive and gram negative bacteria are inhibited by the lichen extract which indicate the presence of broad spectrum antibacterial compound.

\section{CONCLUSSION}

The present work described the antibacterial efficiency and the presence of different phytochemicals of the lichens growing in Kalyani University Campus. The biochemical tests were done for the presence of Tannins, Alkaloids, Saponins, glycosides, Flavonoids, Proteins, Triterpenoids, Carbohydrates and Steroids. Lichens were screening antibacterial properties and it was found that Methanolic and Ethanolic extract shows maximum activity as compare to the water extract indicating the released of bioactive component of lichens in the solvent in greater amount. It is the first time study of antimicrobial activity of Cryptothecia striata and Cryptothecia scripta. However, further investigation on isolation and characterization of the active principle of this lichen species responsible for the antibacterial activity is necessary.

\section{REFERENCES}

Fleishner TL. (1994) Ecological costs of livestock grazing in western north America. Conservation Biology. 8(3) :633. Retrieved from https://doi.org/10.1046/j.1523-1739.1994.08030629.x

Honegger R. Simon Schwendener (1829-1919) and the dual Hypothesis of Lichens. The Bryologist (2009).103(Summer 2000) :307-313. Retrieved from https://www.jstor.org/stable/3244159

Huneck S and Yoshimura I. (1996) Identification of Lichen Substances. DOI :10.1007/978-3-642-85243-5. Retrieved from https://link.springer.com/chapter/10.1007/978-3-642-85243-5_2

Rashmi S and Rajkumar HG. (2014) Preliminary phytochemical screening of different solvent extracts of lichens from Kodagu district, Karnataka. Journal of pharmacognosy and phytochemistry. 3(4) 209-212.

Upreti DK, Divakar PK, Nayaka S (2005). Commercial and ethnic use of lichens in India. Economic Botany. 59(3) 269. Retrieved from https://link.springer.com/article/10.1663/00130001(2005)059[0269:CAEUOL]2.0.CO;2 